\title{
LANGUAGE ACTUALIZATION OF THE CONCEPT FAUNA IN THE MULTILINGUAL PHRASEOLOGICAL WORLDVIEW
}

\author{
МОВНА АКТУАЛІЗАЦІЯ КОНЦЕПТУ ФАУНА \\ В МУЛЬТИЛІНГВАЛЬНІЙ ФРАЗЕОЛОГІЧНІЙ КАРТИНІ СВІТУ
}

\section{ЯЗЫКОВАЯ АКТУАЛИЗАЦИЯ КОНЦЕПТА ФАУНА В МУЛЬТИЛИНГВАЛЬНОЙ ФРАЗЕОЛОГИЧЕСКОЙ КАРТИНЕ МИРА}

The article gives the definition of a notion «concept» and presents its main interpretations in modern linguistic science. This article also describes the notion of «phraseological worldview» and its relation to the notion «concept». Based on the selected phraseological units that actualize the concept FAUNA in three languages - English, Spanish and Ukrainian, their analysis, comparison and classification were carried out. This allowed us to prove that the language actualization of the concept FAUNA, which is based on the material of the English, Spanish and Ukrainian phraseological units, is associated with the identification of national characteristics of the researched cultures. The peculiarities of the phraseological worldview of a particular language are influenced by linguistic and cultural factors, geographical location, customs and traditions of the country. Together with the peculiarities of the world perception of British, Spanish and Ukrainian people, these factors influence the language organization, human traits, ideas and meanings that are embedded in the concepts of various animals.

In the course of the research, the main different and common features of the language actualization of the concept FAUNA in English, Spanish and Ukrainian phraseological worldviews have been discovered.

Keywords: concept, phraseological worldview, multilingual aspect, language actualization, linguistic and cultural factors.

У статті визначено поняття «концепт», представлено його основні інтерпретації у сучасній лінгвістичній науці. В даній роботі також описано поняття «фразеологічна картина світу», його зв'язок 3 поняттям «концепт». На основі відібраних фразеологічних одиниць, що актуалізують концепт ФАУНА в трьох мовах - англійській, іспанській і українській, було проведено їх аналіз, порівняння і класифікацію. Це дозволило довести, що мовна актуалізація концепту ФАУНА, що базується на матеріалі фразеологічних одиниць англійської, іспанської й української мов, пов'язана з виявленням національних особливостей досліджуваних культур. На особливості фразеологічної картині світу тієї чи тієї мови впливають лінгвокультурні фактори, географічне положення, звичаї та традиції країни. Всі ці фактори разом з особливостями світосприйняття британців, 
іспанців і українців впливають на мовну організацію, на те, які риси людського характеру, ідеї і значення закладено в концептах різних тварин.

У процесі дослідження було встановлено основні відмінні та спільни риси мовної актуалізації концепту ФАУНА в англійській, іспанській і українській фразеологічних картинах світу.

Ключові слова: концепт, фразеологічна картина світу, мультилінгвальний аспект, мовна актуалізація, лінгвістичні та культурні фактори.

В статье дано определение понятия «концепт», представлены его основные интерпретации в современной лингвистической науке. В данной работе также дано описание понятия «фразеологическая картина мира», его связь с понятием «концепт». На основе отобранных фразеологических единиц, которые актуализируют концепт ФАУНА в трех языках - английском, испанском и украинском, был проведен их анализ, сравнение и классификация. Это позволило доказать, что языковая актуализация концепта ФАУНА, которая базируется на материале фразеологических единиц английского, испанского и украинского языков, связана с выявлением национальных особенностей исследуемых культур. На особенности фразеологической картины мира того или иного языка влияют лингвокультурные факторы, географическое положение, обычаи и традиции страны. Все эти факторы вместе с особенностями мировосприятия британцев, испанцев и украинцев влияют на языковую организацию, на то, какие черты человеческого характера, идеи и значения заложены в концептах различных животных.

В процессе исследования были установлены основные отличительные и общие черты языковой актуализации концепта ФАУНА в английской, испанской и украинской фразеологических картинах мира.

Ключевые слова: концепт, фразеологическая картина мира, мультилингвальный аспект, языковая актуализация, лингвистические и культурные факторы.

Language and culture are closely related to each other. Linguistic units, especially units on its lexical and phraseological levels, represent a «mirror of national culture» [4].

V.A. Maslova states that phraseological units, reflecting the long process of development of the national culture, are able to capture and transfer certain cultural attitudes and stereotypes, traditions, customs and mentality from one generation to another. On the basis of this statement, we can say that the phraseological worldview most clearly reveals the national and cultural specifics of different languages and linguistic behavior [3, p. 51]. Thus, the phraseological worldview is of specific value for each language.

The issue of the phraseological worldview was considered in the works of such linguists as V.A. Maslova [3], O. A. Salamatina [4], I. A. Solodilova and V. E. Shcherbina [5].

The main peculiarity of the phraseological worldview is the ability to express the spirit of the nation and its mentality in the most vivid figurative way, to capture the cultural and historical experience of the perception of the world in the form of figurative stable expressions [5, p. 69].

It is possible to reconstruct and describe the phraseological worldview with the help of concepts. The issues of the concept and conceptology were considered in the works of such linguists as V. A. Maslova [3], Yu. S. Stepanov [6], A. Akmajian, R. Demers and R. Parnish [8].

Linguists have proposed a number of approaches to defining the notion «concept». V. A. Maslova defines «concept» as a semantic formation marked by linguistic and cultural specificity which characterizes the carriers of a certain ethnic culture [3, p. 36]. Yu. S. Stepanov views the notion of concept primarily in the cultural aspect, understanding the entire culture as a set of concepts and relations between them [6, p. 7].

Such scientists as A. Akmajian, R. Demers and R. Parnish consider a concept as a mental representation, an element of consciousness that plays the role of an intermediary 
between culture and language. The consciousness receives cultural information, where it is filtered, processed, systematized and formed as a concept [8, p. 161].

The novelty of our research consists in the fact that the concept FAUNA, its language actualization in the phraseological worldview has not been considered from the multilingual point of view before.

Concept FAUNA is one of the largest concepts in various phraseological worldviews. Actualized with the help of phraseological units, concept FAUNA reflects the values of society and, as a carrier of socio-cultural information, becomes the means by which one can learn the culture of any nation.

In order to figure out how the concept FAUNA is actualized in the multilingual aspect, English, Spanish and Ukrainian phraseological units, which form a part of the phraseological worldview, were analyzed, compared and classified. For our research, we have used English-Ukrainian phraseological dictionary by K. T. Barantsev [1], SpanishRussian phraseological dictionary by E. I. Levintova [2] and phraseological dictionary of the Ukrainian language by V. M. Bilonozhenko [7]. In the course of the research, 520 English, 508 Spanish and 302 Ukrainian phraseological units which actualize the concept FAUNA have been discovered. These are phraseological units that actualize different representatives of the animal world and can be divided into five groups - «Mammals», «Birds», «Reptiles», «Fish» and «Insects» (on the basis of the scientific classification of Fauna). In our research, we are paying attention to the most and least abundant groups of animals in the English, Spanish and Ukrainian phraseological worldviews.

The aim of our research is to find out the peculiar features of phraseological units that actualize the concept FAUNA and analyze them from the multilingual aspect by taking three languages into consideration - English, Spanish and Ukrainian.

The analysis of the factual material shows that phraseological units actualizing the concept FAUNA are one of the most numerous groups of English, Spanish and Ukrainian phraseological funds. Since ancient times, there has been a relationship between animals and people, which is successfully reflected in phraseology. Animal concepts have been used in phraseological units in order to characterize people, their personal qualities, traits of character, attitude to various spheres of life.

In the English phraseological worldview the most widespread animal concept is «a horse» (45 units), as Equestrian sports continue to be extremely popular in England. Other commonly used animal concepts in the English phraseological worldview are «a cat» (43 units) and «a dog» (37 units). The main reason for it is long and tight human contact with the above-mentioned representatives of the animal world. In addition, the widely used animal concept in the English phraseological worldview is «a fish» (28 units), since the United Kingdom is a country surrounded by water. Another prominent concept in the English phraseological worldview is «a lion» (18 units), which has been the national emblem and symbol of the United Kingdom for centuries.

In the Spanish phraseological worldview, phraseological units with the names of mammals are the most abundant ones and demonstrate a wide range of meanings. The widely used animal concepts in the Spanish phraseological worldview are el gato 'a cat' (50 units), el toro 'a bull' (36 units) and el perro 'a dog' (32 units). People from Madrid (the capital of Spain) often refer to themselves as gatos (cats) and this nickname dates back to centuries ago. Also, cats have been living side by side with Spanish people for a long time and there are a lot of stray cats on the streets of Spain. As for the bull, it is a national cultural symbol and the phenomenon of bullfighting plays an important part 
in Spanish culture. Dogs and breeds developed in Spain are highly valued and honored by this nation.

In most cases, phraseological units with the names of insects and reptiles have a negative connotation in the Spanish phraseological worldview. The negative attitude to these representatives of Fauna in the Spanish ethnoculture is mainly caused by the Mediterranean climate of the country, on the territory of which insects and reptiles prevail and often bother Spaniards.

In the Ukrainian phraseological worldview, the most commonly used animal concepts are собака 'a dog' (35 units), кim 'a cat' (19 units), риба 'a fish' (16 units) and вовк 'а wolf (14 units). Cats and dogs were among the first animals domesticated by Ukrainians. Fishing is one of the most popular hobbies of the male population in Ukraine, and for some, it was and remains a main source of income. A wolf has been the hero of numerous legends and tales of Ukrainian folklore. The wolf was regarded by Ukrainians as a symbol of predation, hunger and speed.

The phraseological units with exotic animal concepts, such as «camel», «crocodile», «tiger», «elephant», are less common in English and Spanish phraseological worldviews and are absolutely absent in the Ukrainian phraseological worldview. It is explained by the fact that these representatives of the animal world are not characteristic of the area and residents of these countries.

The English, Spanish and Ukrainian phraseological units that actualize the concept FAUNA can be divided into three groups. The main criterion for this classification is the degree of similarity and difference in the representation and perception of the concept FAUNA in English, Spanish and Ukrainian phraseological worldviews.

Phraseological units belonging to the first group transfer meanings that are peculiar to both languages using identical animal concepts. In other words, this group unites international phraseological units which are based on universal animal concepts. Analysis of the factual material showed that phraseological units of this group contain biblical expressions, stable expressions in English, Spanish and Ukrainian phraseological worldviews which came from Latin and ancient Greek manuscripts. For example, the following phraseological units which actualize the concept FAUNA are based on biblical plots: a wolf in sheep's clothing - el lobo con piel de oveja - вовк в овечій икурі; a lost sheеp - oveja descarriada - заблукала вівия; to cast pearls before swine-echar perlas a los cerdos - метати бісер перед свинями.

The similarity of animal concepts in various phraseological worldviews can also be revealed as a result of borrowed expressions from Latin and ancient Greek texts. Since many people had access to the cultural heritage of antiquity, some cultural concepts took root in English, Spanish and Ukrainian phraseological worldviews. For example, a Trojan horse - caballo de Troya - Троянський кінь; a dog in the manger-perro del hortelano - собака на сіні.

The second group includes phraseological units that have the same meaning in the English, Spanish and Ukrainian phraseological worldviews, but they are represented by different animal concepts. This group unites locally unmarked phraseological units, which are based on neutral animal concepts, not nationally peculiar.

The peculiarities of this group are revealed in the actualization of different animal concepts in phraseological units with the coincidence of plots and meanings. For example, such phraseological units as when pigs fly, cuando las ranas tengan pelos (literal translation - when frogs grow hair) and коли рак на горі свисне, actualize different concepts but have the same meaning - «never». 
Other bright examples are the following phraseological units: like a bull in a china shop - como un caballo en una cacharrería (literal translation - like a horse in a China shop) - як корова на льоду / як муха в сметані - clumsily; a wise old bird - lobo de mar / marino (literal translation - the sea wolf) - битий (бита) собака / стріляний горобеиь / старий лис - an experienced person.

The third group features English, Spanish and Ukrainian phraseological units that actualize the concept FAUNA and express unique, specific meanings peculiar to a certain nation. Various linguistic factors can testify to the national character of phraseological units, in particular, the presence of ethnocultural realities, proper names, toponyms and folklore notions as one of the concepts of phraseological units. For example, in the Spanish phraseological worldview: encontro Sancho con su rocin (literal translation - Sancho met with his horse) - two of a kind; gato de Madrid (literal translation - Madrid cat) - a native resident of Madrid; ir en caballo de San Francisco - go by foot; gata de Juan Ramos / de Mari-Ramos - a pretender.

In the English phraseological worldview, examples are as following: to twist the Lion's tail - to affect the interests of England; an Irish bull - an obvious absurdity; to fight like Kilkenny cats - to fight desperately; to grin like a Cheshire cat

- to smile with someone's teeth showing.

In the Ukrainian phraseological worldview, the brightest examples are: де Макар телят пасе - very far away; Химині кури розводити - to talk about something unimportant; з вареної крашанки курча висидить - to be extremely cunning. These phraseological units are locally marked and have a vividly expressed national and cultural concept.

Thus, the analysis of phraseological units that actualize the concept FAUNA in different languages shows that they reflect the mental, linguistic and cultural peculiarities of a certain nation, represent one of the most important components of the phraseological worldview. Concept FAUNA, which is actualized with the help of phraseological units, has a pronounced national and cultural specificity. The idea of particular qualities attributed to animals is rooted in the minds of people. It is connected with the cultural traditions of England, Spain and Ukraine, the presence of animals on the territory of these countries, their role in human life and the peculiarities of mentality.

The main peculiarity in the language actualization of the concept FAUNA in English, Spanish and Ukrainian phraseological worldviews is that some animals, for instance, «a dog», «a horse», «a bull», «a cat», occupy the most common positions among the units of the phraseological fund. The presence of the same concept in different worldviews, for instance, «a dog» and «a cat», indicates a common life experience. The difference of the most widepread animal concepts, for instance, «a horse», «a bull» and «a wolf» in English, Spanish and Ukrainian phraseological worldviews respectively, is explained by the varied animal world, as well as historical conditions of the formation of the language and culture of nations.

The prospect of further research is seen in the comparative analysis of the concept FAUNA in the multilingual phraseological worldview, especially from the point of view of the relationships between different languages and cultures.

\section{References}

1. Anglo-ukraïns'kii fraeologichnii slovnik / 2. Ispansko-russkii frazeologicheskii slovar': uklad. K. T. Barantsev. 2-ge vid., vipr. Kiïv.: T-vo «Znannya», 2005. $1056 \mathrm{~s}$. 30000 frazeologicheskikh edinits / pod red. E. I. Levintovoi. Moskva: Rus. yaz., 1985. $1080 \mathrm{~s}$. 
3. Maslova V.A. Lingvokul'turologiya: sovremennoi frazeologii: monografiya. Uchebnoe posobie dlya studentov vysshikh uchebnykh zavedenii. Moskva: Izdatel'skii tsentr «Akademiya», 2001. $208 \mathrm{~s}$.

Orenburg: OGU, 2011. $377 \mathrm{~s}$.

6. Stepanov Yu. S. «Intertekst», «internet», «intersub»ekt» (K osnovaniyam sravnitel'noi kontseptologii). Izv. RAN. ser.: Lit i yaz. Moskva, 2001. № 1. S. 3-11.

4. Salamatina O.A. Rol' komponentovzoonimov $\mathrm{v}$ formirovanii obshchego frazeologicheskogo znacheniya angliiskikh frazeologicheskikh edinits. Mezhdunarodnyi studencheskii nauchnyi vestnik, 2016. № 5.

7. Frazeologichnii slovnik ukraïns'koï movi / uklad.: V. M. Bilonozhenko ta in. Kiïv: Nauk. dumka, 1993. $984 \mathrm{~s}$.

5. Solodilova I.A., Shcherbina V.E. 8. Akmajian A., R. A. Demers, Harnish R. M. Lingvokognitivnye $\mathrm{i}$ diskursivnye aspekty Linguistics, an Introduction to Language and Communication. MIT Press, 1979. 357 p.

Надійшла до редакиї 10.10.2019 